\title{
Respon Pertumbuhan dan Hasil Tanaman Wortel (Daucus carota L.) di Dataran Rendah pada Berbagai Volume Media dan Dosis Ampas Padat Biogas
}

\section{Growth and Yield Response of Carrot (Daucus carota L.) in the Lowlands at Various Media Volumes and Doses of Biogas Solid Waste}

\author{
M. Zaenuddin Syahril Sidiq, Aluh Nikmatullah*, Herman Suheri \\ Program Studi Agroekoteknologi, Fakultas Pertanian, Universitas Mataram \\ *corresponding author, email: aluh_nikmatullah@unram.ac.id
}

Manuscript received: 09-03-2020. Accepted: 06-07-2020

\begin{abstract}
ABSTRAK
Penelitian ini bertujuan untuk mengetahui respon pertumbuhan dan hasil tanaman wortel (Daucus carota L.) di dataran rendah pada berbagai dosis ampas padat biogas dan volume media. Percobaan dilakukan di lahan percobaan Universitas Mataram di Narmada, Lombok Barat, NTB dengan ketinggian $136 \mathrm{~m}$ dpl selama April-Juli 2019. Metode penelitian ini adalah eksperimental dengan Rancangan Acak Kelompok 2 faktor. Faktor pertama adalah volume media yaitu: $2000 \mathrm{~cm}^{3} / 20 \times 20 \mathrm{~cm}, 4000 \mathrm{~cm}^{3} / 25 \mathrm{x}$ $25 \mathrm{~cm}, 5000 \mathrm{~cm}^{3} / 30 \times 25 \mathrm{~cm}$, dan $7000 \mathrm{~cm}^{3} / 30 \times 30 \mathrm{~cm}$. Faktor ke dua adalah dosis ampas padat biogas (bio-slurry): 10 ton/ha, 15 ton/ha, dan 20 ton/ha. Kedua faktor tersebut dikombinasikan sehingga diperoleh 12 kombinasi perlakuan yang dibuat dalam 3 ulangan sehingga terdapat 36 unit percobaan. Hasil penelitian menunjukkan bahwa pemberian dosis bio-slurry berpengaruh terhadap laju pertambahan panjang daun tanaman wortel dan tidak berpengaruh secara nyata terhadap parameter pertumbuhan lainnya atau hasil tanaman wortel di dataran rendah. Dosis 10 ton/ha dan 20 ton/ha menghasilkan pertambahan tinggi tanaman lebih tinggi dari dosis 15 ton/ha. Volume media berpengaruh terhadap laju pertambahan panjang daun, laju pertambahan jumlah daun, berat berangkasan basah daun, berat berangkasan basah dan kering umbi dan panjang umbi. Volume media $5000 \mathrm{~cm}^{3}$ dan $7000 \mathrm{~cm}^{3}$ menghasilkan pertumbuhan dan hasil tanaman wortel di dataran rendah lebih tinggi dari volume media $2000 \mathrm{~cm}^{3}$ dan $4000 \mathrm{~cm}^{3}$. Tidak terjadi interaksi antara dosis Bio-slurry dengan volume media dalam mempengaruhi pertumbuhan dan hasil tanaman wortel di dataran rendah.
\end{abstract}

Kata Kunci: berangkasan; biogas; bio-slurry; segar; umbi

\footnotetext{
ABSTARCT

This study aimed to determine the growth responses and yield of carrot (Daucus carota L.) grown at the lowland at various rates of biogas solid waste and media volumes. The experiment was carried out at Mataram University experimental field in Narmada, West Lombok, NTB with an altitude of $136 \mathrm{~m}$ above sea level, from April to July 2019. The experiment was designed according a factorialy Randomized Completed Block Design (RCBD). The first factor consisted of 4 volumes of the media
} 
which i.e: $2000 \mathrm{~cm}^{3} / 20 \times 20 \mathrm{~cm}, 4000 \mathrm{~cm}^{3} / 25 \times 25 \mathrm{~cm}, 5000 \mathrm{~cm}^{3} / 30 \times 25 \mathrm{~cm}$ and $7000 \mathrm{~cm}^{3} / 30 \times 30 \mathrm{~cm}$. The second factor consisted of 3 levels of biogas solid waste (bio-slurry) with i.e: 10 tons/ha, 15 tons/ha, and 20 tons/ha. These two factors were combined resulted in 12 treatment combinations. Each treatment was repeated so there was 36 experimental units each with replicate. The results showed that the rates of bio-slurry affected the rate of increase in carrot leaf length and did not significantly affect the other parameters or yield of carrot plants in the lowlands. Rates of 10 tons/ha and 20 tons/ha produced a higher leaf length than 15 tons / ha. The media volumes influenced the rate of increase in leaf length, rate of increase in the number of leaves, plant fresh weight, dry tap root weight and tap root length. The media volume of $5000 \mathrm{~cm}^{3}$ and $7000 \mathrm{~cm}^{3}$ resulted higher growth and yield of carrot plants in the lowlands rates of the media volume of $2000 \mathrm{~cm}^{3}$ and $4000 \mathrm{~cm}^{3}$. There was no interaction between the bio-slurry rates and the media volumes in influencing the growth and yield of carrot plants in the lowland.

Keywords: biomass; biogas; bio-slurry; fresh; tuber

\section{PENDAHULUAN}

Wortel (Daucus carota L.) merupakan komoditas hortikultura yang tergolong sayuran segar. Sayuran ini diminati masyarakat karena harganya yang relatif murah, rasanya enak dan mudah dalam pengolahannya baik dalam bentuk makanan maupun minuman serta kandungan gizi yang tinggi. Wortel dikenal masyarakat Indonesia sebagai sumber vitamin A karena memiliki kadar korotenoid (provitamin A) sebesar $7.63 \pm 0.33^{\circ} \mu \mathrm{g} / \mathrm{g}$ (Adelina et al., 2013). Kandungan gizi umbi wortel per $100 \mathrm{~g}$ adalah energi sebanyak $172 \mathrm{~kJ}$ atau $41 \mathrm{kkal}$, lemak sebesar $0.24 \mathrm{~g}$, lemak jenuh sebesar $0.037 \mathrm{~g}$, lemak tak jenuh ganda sebasar $0.117 \mathrm{~g}$, lemak tak jenuh tunggal sebasar $0.014 \mathrm{~g}$, kolesterol sebesar $0 \mathrm{mg}$, protein sebesar $0.93 \mathrm{~g}$, karbohidrat sebesar $9.58 \mathrm{~g}$, serat sebesar $2.8 \mathrm{~g}$, gula sebesar $4.54 \mathrm{~g}$, sodium $69 \mathrm{~g}$ dan kalium sebesar $320 \mathrm{mg}$ (Anonim, 2018).

Tanaman wortel merupakan tanaman yang dapat tumbuh dengan baik pada dataran tinggi. Meskipun demikian, terdapat varietas wortel yang dapat tumbuh di dataran medium dan rendah seperti varietas New Nantes dan New Kuroda. Hasil penelitian Mardin dan Dewanto (2009) menunjukan bahwa varietas New Kuroda mampu tumbuh normal dan menghasilkan umbi saat dibudidayakan di dataran rendah $( \pm 110 \mathrm{~m} \mathrm{dpl})$. Selain itu varietas Gundaling dapat tumbuh dan berproduksi di dataran rendah (Zawani et al., 2018). Varietas wortel yang memiliki adaptasi terbaik adalah Varietas Cisarua, berdasarkan parameter daya kecambah benih, bobot umbi, tingkat serangan penyakit busuk daun dan tingkat kemanisan daging (Firmansyah et al.,. 2016). Budidaya wortel di dataran rendah dapat dilakukan di lahan (Hidayat, 2019) atau di polibag (Amalia, 2019).Pengembangan budidaya wortel di dalam polibag diperlukan sebagai upaya untuk mendukung program pemerintah untuk meningkatkan ketahanan berbasis ketahanan pangan rumah tangga melalui pemanfaatan pekarangan dengan program Kawasan Rumah Pangan Lestari (KRPL) (Nikmatullah et al., 2018).

Volume media tanam menjadi salah satu faktor penentu budidaya wortel di dalam polibag. Volume media yang baik untuk budidaya tanaman adalah volume media yang mampu menunjang pertumbuhan dan perkembangan akar serta mencukupi kebutuhan tanaman akan air dan unsur hara. Pada saat ini tersedia polybag dengan berbagai ukuran volume media dari ukuran 8 × $9 \mathrm{~cm}$ sampai dengan $60 \times 60 \mathrm{~cm}$. Semakin besar volume media yang digunakan maka ruang, unsur hara, dan air yang dibutuhkan tanaman akan dapat tersedia, sebaliknya jika volume media yang digunakan semakin kecil maka ruang tumbuh, unsur hara dan air akan 
semakin sedikit. Pemilihan volume media yang akan digunakan tergantung dari jenis tanaman yang akan ditanam (Muliawati, 2001).

Ketersediaan media tanam menjadi salah satu kendala yang dihadapi dalam budidaya di pekarangan. Ketersediaan media merupakan faktor yang sangat menentukan dalam budidaya di pekarangan menggunakan polibag. Media yang digunakan dalam budidaya di pekarangan diambil dari tempat lain. Oleh karena itu, perlu volume media yang efisien dan tetap dapat mendukung pertumbuhan dan perkembangan tanaman secara optimal.

Selain volume media, kecukupan unsur hara akan menentukan pertumbuhan dan hasil tanaman. Unsur hara adalah sumber nutrisi atau makanan yang dibutuhkan tanaman, baik itu unsur hara yang tersedia di media tanam maupun yang sengaja ditambahkan. Unsur hara digolongkan menjadi dua yaitu unsur hara makro $(\mathrm{K}, \mathrm{S}, \mathrm{Ca}, \mathrm{P}, \mathrm{Mg}$, dan $\mathrm{N}$ ) dan unsur hara mikro ( $\mathrm{Zn}, \mathrm{Cu}$, $\mathrm{Fe}, \mathrm{Mo}, \mathrm{B}, \mathrm{Mn}$, dan $\mathrm{Cl}$ ). Unsur hara makro cenderung dibutuhkan dalam jumlah banyak oleh tanaman dan unsur hara mikro dibutuhkan dalam jumlah sedikit oleh tanaman (Muliawati, 2001). Unsur hara makro yang banyak dibutuhkan oleh tanaman salah satunya adalah unsur hara N. Arang sekam merupakan salah satu campuran media tanam yang memiliki kandungan unsur hara $\mathrm{N}$ yang sangat tinggi dibandingkan dengan kandungan unsur hara $\mathrm{N}$ dalam tanah (Sofyan et al., 2014).

Wortel merupakan sayuran segar yang banyak dikonsumsi oleh masyarakat, oleh karena itu dalam budidaya tanaman wortel sebaiknya menggunakan sumber unsur hara yang tidak mengandung bahan kimia. Salah satu pupuk yang dapat digunakan adalah ampas padat biogas (bio-slurry) yang sudah tersedia cukup melimpah di NTB. Bio-slurry atau ampas biogas merupakan produk dari hasil pengolahan biogas berbahan kotoran ternak dan air melalui proses tanpa oksigen (anaerobik) di dalam ruang tertutup. Bio-slurry sebagai pupuk organik mempunyai kandungan bahan organik yang cukup tinggi $(68,59 \%)$ dan $\mathrm{C} / \mathrm{N}$ (9,09\%) yang bermanfaat untuk memperbaiki struktur tanah. Tanah yang diberi bio-slurry menjadi lebih gembur serta mudah mengikat nutrisi dan air. Bio-slurry juga meningkatkan populasi dan aktivitas mikro organisme tanah (Anonim, 2015).

Belum tersedia informasi yang memadai tentang pengaruh kombinasi penggunaan berbagai dosis ampas padat biogas dengan volume media pada budidaya wortel di dataran rendah. Berdasarkan uraian di atas maka dilakukan penelitian tentang "Responn Pertumbuhan dan Hasil Tanaman Wortel (Daucus carota L.) di Dataran Rendah pada Berbagai Dosis Ampas Padat Biogas dan Volume Media”.

\section{Tempat, Waktu, dan Bahan Percobaan}

\section{BAHAN DAN METODE}

Penelitian ini dilakukan di lahan percobaan Universitas Mataram yang bertempat di Narmada, Lombok Barat, NTB dengan ketinggian 136 m dpl. Penelitian ini dilaksanakan pada bulan April sampai dengan bulan Juli 2019. Benih yang digunakan adalah benih wortel varietas Gundaling Benih tersebut diperoleh dari BBI Kuta Gadung, Berastagi, Sumatra Utara.

\section{Perlakuan dan Desain Percobaan}

Percobaan dirancang dengan Rancangan Acak Kelompok (RAK) faktorial. Faktor pertama adalah dosis ampas padat biogas (d) dengan 3 taraf yaitu d1 (dosis 10 ton/ha), d2 (dosis 15 ton/ha), dan d3 (dosis 20 ton/ha). Faktor kedua adalah volume media (v) dengan 4 taraf yaitu v1 $\left(2000 \mathrm{~cm}^{3} / 20 \times 20 \mathrm{~cm}\right), \mathrm{v} 2\left(4000 \mathrm{~cm}^{3} / 25 \times 25 \mathrm{~cm}\right) . \mathrm{v} 3\left(5000 \mathrm{~cm}^{3} / 30 \times 25 \mathrm{~cm}\right)$, dan v4 $(7000$ 
$\mathrm{cm}^{3} / 30$ x $30 \mathrm{~cm}$ ). Interaksi kedua perlakuan dikombinasikan sehingga diperoleh 12 perlakuan dan setiap perlakuan diulang 3 kali sehingga diperoleh 36 unit percobaan.

\section{Pelaksanaan Percobaan}

Percobaan dilaksanakan mulai dari persiapan media tanam. Media tanam yang digunakan yaitu campuran tanah topsoil dan arang sekam yang dicampur dengan perbandingan 1:1. Benih yang digunakan dalam percobaan ini adalah benih wortel varietas Gundaling. Benih wortel langsung ditanam (disebar) tanpa melalui persemaian terlebih dahulu pada kedalaman 2 $\mathrm{cm}$ dan ditutup dengan media setebal $1 \mathrm{~cm}$. Waktu penyiraman dilakukan pada pagi dan sore hari dan dilakukan sejak penanaman hingga tanaman menghasilkan umbi. Penjarangan tanaman wortel dilakukan pada saat tanaman berumur 4 minggu setelah tanam dan penyiangan dilakukan 2 minggu sekali seminggu dengan cara mencabut gulma-gulma yang tumbuh di sekitar tanaman wortel dan polibag.

Pemupukan dilakukan menggunakan pupuk ampas padat biogas dengan dosis sesuai perlakuan. Adapun dosis pupuk yang diberikan adalah sebagai berikut:

Tabel 1. Perlakuan Dosis Ampas Padat Biogas pada setiap Volume Media

\begin{tabular}{|c|c|c|c|c|}
\hline \multirow{2}{*}{ Volume Media } & \multirow{2}{*}{ Dosis Pupuk } & \multicolumn{2}{|c|}{ Dosis (g/polybag) } & \multirow{2}{*}{ Total } \\
\hline & & Dasar & Susulan & \\
\hline \multirow{3}{*}{ V1 } & d1 (10 ton/ha) & 5.00 & 5.00 & $10 \mathrm{~g}$ \\
\hline & d2 (15 ton/ha) & 7.00 & 7.00 & $14 \mathrm{~g}$ \\
\hline & d3 (20 ton/ha) & 9.50 & 9.50 & $19 \mathrm{~g}$ \\
\hline \multirow{3}{*}{ V2 } & d1 (10 ton/ha) & 10.00 & 10.00 & $20 \mathrm{~g}$ \\
\hline & d2 (15 ton/ha) & 15.00 & 15.00 & $30 \mathrm{~g}$ \\
\hline & d3 (20 ton/ha) & 20.00 & 20.00 & $40 \mathrm{~g}$ \\
\hline \multirow{3}{*}{ V3 } & d1 (10 ton/ha) & 12.50 & 12.50 & $25 \mathrm{~g}$ \\
\hline & d2 (15 ton/ha) & 19.00 & 19.00 & $38 \mathrm{~g}$ \\
\hline & d3 (20 ton/ha) & 25.00 & 25.00 & $50 \mathrm{~g}$ \\
\hline \multirow{3}{*}{ V4 } & d1 (10 ton/ha) & 17.50 & 17.50 & $35 \mathrm{~g}$ \\
\hline & d2 (15 ton/ha) & 26.50 & 26.50 & $53 \mathrm{~g}$ \\
\hline & d3 (20 ton/ha) & 35.50 & 35.50 & $71 \mathrm{~g}$ \\
\hline
\end{tabular}

Keterangan: Asumsi volume media/ha dengan lapisan olah tanah $20 \mathrm{~cm}$.

Pengendalian OPT dilakukan dengan menggunakan Metarhizium anisopliae yang diberikan 3 kali yaitu pada saat tanam, pada umur 5 minggu dan 10 minggu dan menggunakan Beuveria bassiana yang diaplikasikan pada umur 2, 4, 6, 8, dan 10 minggu setelah tanam. Apabila serangan hama sedikit dapat dikendalikan dengan cara mekanis dan dapat melakukan penyemprotan ekstrak daun nimba untuk mengatasi ulat grayak pada pagi dan sore hari.

Pertumbuhan tanaman diamati dengan menghitung laju pertambahan panjang daun, laju pertambahan jumlah daun, berat biomassa basah dan kering tanaman. Laju pertambahan panjang daun dan laju pertambahan jumlah tanaman dihitung dengan analisa regresi linier dari fungsi panjang daun atau jumlah daun per dua minggu. Berat biomassa segar tanaman baik daun maupun umbi ditimbang menggunakan timbangan digital, sedangkan berat biomassa kering daun maupun umbi diukur setelah biomassa tanaman dikeringkan dalam oven pada suhu $70^{\circ} \mathrm{C}$ sampai mencapai berat konstan dan ditimbangan dengan timbangan digital. 
Hasil dan mutu hasil tanaman wortel diamati setelah panen pada parameter panjang umbi, diamter umbi (diukur dengan jangka sorong), kekerasan umbi (diukur dengan penetrometer), dan kadar gula umbi (diukur dengan refraktometer). Data hasil percobaan dianalisis menggunakan Analysis of Variance (ANOVA) pada taraf nyata $5 \%$. Jika ada perlakuan yang berbeda nyata, maka dilakukan diuji lanjut dengan menggunakan uji Beda Nyata Jujur (BNJ) pada taraf nyata $5 \%$.

\section{HASIL DAN PEMBAHASAN}

Hasil percobaan dalam penelitian in, menunjukkan bahwa volume media berpengaruh terhadap sebagian besar parameter pertumbuhan dan hasil tanaman wortel di dataran rendah kecuali terhadap diameter rata-rata umbi, berat berangkasan kering daun, kekerasan umbi dan kemanisan umbi. Dosis ampas padat biogas (bio-slurry) berpengaruh nyata terhadap parameter laju pertambahan panjang daun wortel, namun tidak berpengaruh terhadap parameter pertumbuhan dan hasil lainnya. Tabel 2 juga menunjukkan bahwa tidak terdapat interaksi yang terjadi antara dosis pupuk dengan volume media dalam mempengaruhi pertumbuhan dan hasil tanaman wortel di dataran rendah.

Pada perlakuan volume media, laju pertambahan panjang daun meningkat dengan bertambahnya ukuran volume media yang digunakan dengan volume media $7000 \mathrm{~cm} 3$ memiliki laju pertambahan panjang daun $9.23 \mathrm{~cm} / 2$ minggu yang tidak berbeda nyata dengan volume media $4000 \mathrm{~cm} 3$ dan $5000 \mathrm{~cm} 3$ dengan laju pertambahan panjang daun berturut-turut yaitu 7.99 dan $8.69 \mathrm{~cm} / 2$ minggu. Laju pertambahan panjang daun terendah terdapat pada volume media $2000 \mathrm{~cm} 3$ yaitu $7.51 \mathrm{~cm} / 2$ minggu. Laju pertambahan yang lebih tinggi adalah pada volume media $5000 \mathrm{~cm} 3$ dan $7000 \mathrm{~cm} 3$, volume media $5000 \mathrm{~cm} 3$ yaitu 2.14 helai $/ 2$ minggu dan volume media $7000 \mathrm{~cm} 3$ dengan rata-rata 2.02 helai $/ 2$ minggu. Meskipun volume media $7000 \mathrm{~cm} 3$ tidak signifikan dengan volume media $4000 \mathrm{~cm} 3 \mathrm{dan}$ nilai terendah terdapat pada volume media $2000 \mathrm{~cm} 3$ yaitu 1.57 helai $/ 2$ minggu.

Tabel 3. Laju Pertambahan Panjang Daun dan Laju Pertambahan Jumlah Daun Tanaman Wortel di Dataran Rendah pada Berbagai Dosis Bio-slurry dan Volume Media.

\begin{tabular}{ccc}
\hline Perlakuan & $\begin{array}{c}\text { Laju Pertambahan Panjang } \\
\text { Daun }(\mathbf{c m} / \mathbf{2} \text { minggu) }\end{array}$ & $\begin{array}{c}\text { Laju Pertambahan Jumlah } \\
\text { daun (helai/2 minggu) }\end{array}$ \\
\hline Volume media & $7.51 \mathrm{~b}$ & $1.57 \mathrm{c}$ \\
v1: $2000 \mathrm{~cm}^{3}$ & $7.99 \mathrm{ab}$ & $1.73 \mathrm{bc}$ \\
v2: $4000 \mathrm{~cm}^{3}$ & $8.69 \mathrm{ab}$ & $2.14 \mathrm{a}$ \\
v3: $5000 \mathrm{~cm}^{3}$ & $9.23 \mathrm{a}$ & $2.02 \mathrm{ab}$ \\
v4: $7000 \mathrm{~cm}^{3}$ & 1.33 & 0.40 \\
\hline BNJ 5\% & & \\
\hline Dosis pupuk & $9.16 \mathrm{a}$ & $1.88 \pm 0.22$ \\
10 ton/ha & $7.43 \mathrm{~b}$ & $1.79 \pm 0.28$ \\
15 ton/ha & $8.48 \mathrm{a}$ & $1.93 \pm 0.33$ \\
\hline 20 ton/ha & 1.04 & - \\
\hline BNJ 5\% &
\end{tabular}

Keterangan: Angka-angka pada kolom yang sama yang diikuti oleh huruf yang sama tidak berbeda nyata bedasarkan uji BNJ pada taraf nyata $5 \%$. 
Tabel 3 menunjukkan bahwa, nilai rata-rata laju pertambahan panjang daun pada perlakuan dosis 10 ton/ha $(9.16 \mathrm{~cm} / 2$ minggu) dan perlakuan dosis 20 ton/ha $(8.48 \mathrm{~cm} / 2 \mathrm{minggu})$ nyata lebih tinggi dibandingkan dengan perlakuan dosis 15 ton/ha $(7.43 \mathrm{~cm} / 2 \mathrm{minggu})$. Laju pertambahan panjang daun pada dosis 10 ton/ha tidak berbeda nyata dengan dosis 20 ton/ha, namun lebih tinggi dari perlakuan dosis 15 ton/ha dan pada laju pertambahan jumlah daun pada dosis 15 ton/ha menjadi nilai terendah yaitu 1.79 helai/2 minggu.

Penggunaan berbagai volume media berpengaruh nyata terhadap berat berangkasan basah daun namun tidak berpengaruh nyata terhadap berat berangkasan kering daun. Semakin besar volume media yang digunakan, berat berangkasan daun semakin tinggi dengan volume media $7000 \mathrm{~cm} 3$ menghasilkan berat berangkasan daun $21.48 \mathrm{~g}$ yang lebih tinggi dari volume media $4000 \mathrm{~cm} 3$ dan $2000 \mathrm{~cm} 3$, meskipun tidak signifikan dengan volume media $5000 \mathrm{~cm} 3$ yaitu $17.77 \mathrm{~g}$. Pola tersebut cenderung sama pada berat berangkasan kering dengan volume media $7000 \mathrm{~cm} 3$ menghasilkan berat kering cenderung paling tinggi yaitu $3.70 \mathrm{~g}$ dan volume media $2000 \mathrm{~cm} 3$ cenderung pling rendah yaitu $1.87 \mathrm{~g}$.

Tabel 4. Hasil Pengamatan Berat Berangkasan Basah dan Kering Daun pada Berbagai Dosis Bio-slurry dan Volume Media.

\begin{tabular}{ccc}
\hline Perlakuan & Berangkasan Basah $(\mathbf{g})$ & Berangkasan Kering $(\mathbf{g})$ \\
\hline Volume media & & \\
v1: $2000 \mathrm{~cm}^{3}$ & $8.33 \mathrm{c}$ & $1.87 \pm 0.61$ \\
v2: $4000 \mathrm{~cm}^{3}$ & $11.33 \mathrm{bc}$ & $3.34 \pm 0.58$ \\
v3: $5000 \mathrm{~cm}^{3}$ & $17.77 \mathrm{ab}$ & $3.54 \pm 0.53$ \\
v4: $7000 \mathrm{~cm}^{3}$ & $21.48 \mathrm{a}$ & $3.70 \pm 1.00$ \\
\hline BNJ 5\% & 9.14 & - \\
\hline Dosis pupuk & & \\
10 ton/ha & $13.36 \pm 4.95$ & $2.41 \pm 0.87$ \\
15 ton/ha & $13.66 \pm 4.17$ & $2.69 \pm 0.78$ \\
20 ton/ha & $17.16 \pm 4.92$ & $4.26 \pm 0.87$ \\
\hline BNJ 5\% & - & - \\
\hline
\end{tabular}

Keterangan: hst $=$ hari setelah tanam, Angka-angka pada kolom yang sama diikuti huruf yang sama menunjukkan tidak berbeda nyata bedasarkan uji BNJ pada taraf nyata $5 \%$.

Hasil analisis keragaman menunjukkan bahwa pemberian bio-slurry dengan berbagai dosis tidak bepengaruh terhadap berat berangkasan basah dan berat berangkasan kering daun, akan tetapi ada kecendrungan dosis 20 ton/ha menghasilkan berat berangkasan basah dan kering daun lebih tinggi dari dosis 10 dan 15 ton/ha yaitu $17.16 \mathrm{~g}$ dan $4.26 \mathrm{~g}$.

Pada perlakuan volume media, berat berangkasan basah dan kering umbi nyata lebih tinggi pada volume media $7000 \mathrm{~cm}^{3}, 5000 \mathrm{~cm}^{3}$ dan $4000 \mathrm{~cm}^{3}$, meskipun hasil umbi pada volume media $4000 \mathrm{~cm}^{3}$ tidak signifikan dengan volume media $2000 \mathrm{~cm}^{3}$. Hasil berat berangkasan basah pada volume media $7000 \mathrm{~cm}^{3}$ tidak berbeda nyata dengan volume media $4000 \mathrm{~cm}^{3}$ dan $5000 \mathrm{~cm}^{3}$ berturut-turut yaitu $43.2 \mathrm{~g}, 26.6 \mathrm{~g}$, dan $42.7 \mathrm{~g}$. Sedangkan pada berat berangkasan kering didapatkan hasil paling tinggi juga terdapat pada volume media 7000 $\mathrm{cm}^{3}$ dan $5000 \mathrm{~cm}^{3}$ yaitu berturut-turut $6.24 \mathrm{~g}$ dan $6.03 \mathrm{~g}$, meskipun tidak signifikan dengan volume media $4000 \mathrm{~cm}^{3}$ dengan berat berangkasan kering umbi $3.72 \mathrm{~g}$. Nilai terendah didapatkan pada volume media $2000 \mathrm{~cm}^{3}$ baik pada parameter berat berangkasan basah maupun berangkasan kering umbi dengan nilai $13.88 \mathrm{~g}$ dan $2.17 \mathrm{~g}$. 
Tabel 5. Hasil Pengamatan Berat Brangkasan Basah dan Kering Umbi Wortel pada Berbagai Dosis Bio-slurry dan Volume Media.

\begin{tabular}{ccc}
\hline Perlakuan & Brangkasan Basah $(\mathbf{g})$ & Brangkasan Kering $(\mathbf{g})$ \\
\hline Volume media & $13.88 \mathrm{~b}$ & $2.17 \mathrm{~b}$ \\
v1: $2000 \mathrm{~cm}^{3}$ & $26.60 \mathrm{ab}$ & $3.72 \mathrm{ab}$ \\
$\mathrm{v} 2: 4000 \mathrm{~cm}^{3}$ & $42.66 \mathrm{a}$ & $6.03 \mathrm{a}$ \\
$\mathrm{v} 3: 5000 \mathrm{~cm}^{3}$ & $43.20 \mathrm{a}$ & $6.24 \mathrm{a}$ \\
$\mathrm{v} 4: 7000 \mathrm{~cm}^{3}$ & 21.07 & 3.06 \\
\hline BNJ 5\% & $25.76 \pm 10.17$ & \\
\hline Dosis pupuk & $31.58 \pm 12.30$ & $4.35 \pm 1.83$ \\
10 ton/ha & $37.41 \pm 10.60$ & $4.38 \pm 1.62$ \\
15 ton/ha & - & $4.88 \pm 1.30$ \\
20 ton/ha & & - \\
\hline BNJ 5\% & &
\end{tabular}

Keterangan: hst = hari setelah tanam, Angka - angka pada kolom yang sama diikuti huruf yang sama menunjukkan tidak berbeda nyata bedasarkan uji BNJ pada taraf nyata $5 \%$.

Pemberian bio-slurry dengan berbagai dosis tidak bepengaruh terhadap berat berangkasan basah dan berat berangkasan kering umbi, sedangkan penggunaan berbagai volume media berpengaruh terhadap berat berangkasan basah dan berat berangkasan kering tanaman wortel. Ada kecenderungan bahwa pemberian dosis 20 ton/ha menghasilkan berat berangkasan basah dan berangkasan kering umbi tertinggi, yaitu berturut-turut $37.41 \mathrm{~g}$ dan $4.88 \mathrm{~g}$, sedangkan dosis 10 ton/ha menghasilkan berat terendah yaitu berturut-turut $25.76 \mathrm{~g}$ dan $4.35 \mathrm{~g}$.

Tabel 6. Hasil Pengamatan Panjang dan Diameter Umbi Wortel pada Berbagai Dosis Bioslurry dan Volume Media.

\begin{tabular}{ccc}
\hline Perlakuan & Panjang Umbi (cm) & Diameter Umbi $(\mathbf{c m})$ \\
\hline Volume media & & \\
v1: $2000 \mathrm{~cm}^{3}$ & $8.88 \mathrm{~b}$ & $1.46 \pm 0.42$ \\
$\mathrm{v} 2: 4000 \mathrm{~cm}^{3}$ & $11.31 \mathrm{ab}$ & $1.38 \pm 0.22$ \\
v3: $5000 \mathrm{~cm}^{3}$ & $14.00 \mathrm{a}$ & $1.80 \pm 0.17$ \\
$\mathrm{v} 4: 7000 \mathrm{~cm}^{3}$ & $13.01 \mathrm{a}$ & $1.82 \pm 0.23$ \\
\hline BNJ 5\% & 3.68 & - \\
\hline Dosis pupuk & & \\
10 ton/ha & $10.82 \pm 2.01$ & $1.59 \pm 0.42$ \\
15 ton/ha & $12.41 \pm 2.11$ & $1.53 \pm 0.23$ \\
20 ton/ha & $12.16 \pm 1.49$ & $1.72 \pm 0.27$ \\
\hline BNJ 5\% & - & -
\end{tabular}

Keterangan: hst $=$ hari setelah tanamAngka-angka pada kolom yang sama diikuti huruf yang sama menunjukkan tidak berbeda nyata bedasarkan uji BNJ pada taraf nyata $5 \%$.

Hasil analisis keragaman menunjukkan perlakuan dosis bio-slurry tidak berpengaruh terhadap parameter panjang dan diameter umbi dengan panjang umbi berkisar antara 10.82 g sampai $12.41 \mathrm{~g}$ dan diameter umbi $1.53 \mathrm{~cm}$ sampai $1.72 \mathrm{~cm}$. Sedangkan pada volume media, panjang umbi lebih tinggi terdapat pada volume media $5000 \mathrm{~cm}^{3}$ dan $7000 \mathrm{~cm}^{3}$ yaitu 
$14 \mathrm{~cm}$ dan $13.01 \mathrm{~cm}$, meskipun tidak signifikan dengan volume media $4000 \mathrm{~cm}^{3}$ dengan hasil panjang umbi $11.31 \mathrm{~cm}$. Hasil terendah didapatkan pada volume media $2000 \mathrm{~cm}^{3}$ yaitu $8.88 \mathrm{~cm}$, meskipun tidak signifikan dengan volume media $4000 \mathrm{~cm}^{3}$.

Hasil analisis keragaman menunjukkan bahwa perlakuan volume media dan dosis bio-slurry tidak berpengaruh nyata terhadap paremeter tingkat kekerasan dan kemanisan umbi. Rata-rata tingkat kekerasan umbi pada berbagai dosis bio-slurry dan semua volume media didapatkan hasil yaitu $3.5 \mathrm{~kg} / \mathrm{cm} 2$. Tingkat kemanisan umbi pada dosis $20 \mathrm{ton} / \mathrm{ha}$ cenderung lebih tinggi dari pada kemanisan umbi pada dosis 10 ton/ha dam 15 ton/ha yaitu berturut-turut $17.3^{\circ} \mathrm{Brix}, 16.2^{\circ} \mathrm{Brix}$, dan $16.8^{\circ} \mathrm{Brix}$. Tingkat kemanisan umbi tertinggi diperoleh dari tanaman yang di tanam pada volume media $4000 \mathrm{~cm} 3$ dan terendah terdapat pada volume media $7000 \mathrm{~cm} 3$ yaitu berturut-turut $17.1^{\circ} \mathrm{Brix}$ dan $13.4^{\circ} \mathrm{Brix}$.

Tabel 8. Kandungan Unsur Hara Media Tanam dan Ampas Padat Biogas (bio-slurry).

\begin{tabular}{|c|c|c|c|}
\hline Sampel & Parameter Analisa & Nilai & Kategori \\
\hline Tanah & $\begin{array}{l}\mathrm{pH} \\
\text { C-Organik }(\%) \\
\text { N-Total }(\%) \\
\text { P-Tersedia }(\mathrm{ppm}) \\
\text { K-Tersedia }(\mathrm{ppm})\end{array}$ & $\begin{array}{r}7.5 \\
1.50 \\
0.11 \\
15.27 \\
98.44 \\
\end{array}$ & $\begin{array}{c}\text { Netral } \\
\text { Rendah* } \\
\text { Rendah* } \\
\text { Sangat Tinggi* } \\
\text { Sangat Tinggi* }\end{array}$ \\
\hline $\begin{array}{l}\text { Ampas padat Biogas } \\
\text { (bio-slurry) }\end{array}$ & $\begin{array}{l}\mathrm{pH} \\
\text { C-Organik (\%) } \\
\text { C/N (\%) } \\
\text { N-Total }(\%) \\
\text { P-Tersedia }(\%) \\
\text { K-Tersedia }(\%)\end{array}$ & $\begin{array}{r}6.32 \\
1.48 \\
12.33 \\
0.12 \\
1.02 \\
1.10\end{array}$ & $\begin{array}{c}\text { Netral } \\
\text { Rendah* } \\
\text { Sedang* } \\
\text { Rendah* } \\
\text { Sangat Tinggi* } \\
\text { Sangat Tinggi* }\end{array}$ \\
\hline
\end{tabular}

Keterangan: Berdasarkan hasil analisis kimia media tanam dan pupuk, Laboratorium Penguji Balai Pengkajian Teknologi Pertanian (BPTP) NTB (2019). * Berdasarkan kriteria Balai Penelitian Tanah, Badan Penelitian dan Pengembangan Pertanian, Departemen Pertanian (Prijatna, 2006).

Hasil analisa kimia media tanam dan pupuk pada Tabel 8 di peroleh bahwa media tanam mengandung C-organik dengan kategori rendah, N-total rendah, P-tersedia sangat tinggi dan K-tersedia sangat tinggi, sedangkan dalam bio-slurry mengandung C-organik dengan kategori rendah, $\mathrm{C} / \mathrm{N}$ ratio sedang, $\mathrm{N}$-total rendah, $\mathrm{P}$ dan $\mathrm{K}$ tersedia sangat tinggi.

Pembahasan

Pengaruh Aplikasi Dosis Bio-slurry Terhadap Pertumbuhan Vegetatif Tanaman dan Hasil Panen Umbi

Pemupukan bertujuan untuk melengkapi penyediaan hara yang ada dalam tanah untuk memenuhi kebutuhan tanaman dan memperbaiki kondisi tanah yang kurang baik atau mempertahankan kondisi tanah yang sudah baik untuk pertumbuhan tanaman. Bio-slurry atau ampas biogas merupakan produk dari hasil pengolahan biogas berbahan kotoran ternak dan air melalui proses tanpa oksigen (anaerobik) di dalam ruang tertutup. Bio-slurry dapat digunakan sebagai pupuk organik karena mempunyai kandungan bahan organik $(68,59 \%)$ dengan $\mathrm{C} / \mathrm{N}$ ratio $9.09 \%$ ) yang bermanfaat untuk memperbaiki struktur tanah. Tanah yang 
diberi bio-slurry menjadi lebih gembur serta mudah mengikat nutrisi dan air juga meningkatkan populasi dan aktivitas mikro organisme tanah (Anonim, 2015).

Berdasarkan hasil percobaan diketahui dosis pupuk berpengaruh secara nyata terhadap laju pertambahan panjang daun dan tidak berpengaruh terhadap parameter pertumbuhan lainnya dan hasil wortel di dataran rendah (Tabel 2). Dosis 10 ton/ha dan 20 ton/ha menghasilkan pertambahan panjang daun lebih tinggi dibandingkan dosis 15 ton/ha. Laju pertambahan panjang daun pada dosis 10 ton/ha sebesar $9.16 \mathrm{~cm} / 2 \mathrm{minggu}$, dosis 20 ton/ha $8.48 \mathrm{~cm} / 2$ minggu dan dosis 15 ton/ha menghasilkan laju pertambahan panjang daun terendah yaitu $7.43 \mathrm{~cm} / 2$ minggu. Pada pemberian dosis 15 ton/ha terjadi penurunan tingkat laju pertambahan panjang daun. Hal ini diduga disebabkan oleh faktor ketersediaan unsur hara yang berbeda pada media tanam dan setiap tanaman memilliki tipe jaringan yang berbeda sehingga kemampuan dan tingkat toleransi penyerapan unsur hara berbeda sehingga kandungan hara yang terserap oleh tanaman juga bervariasi (Siahaan et al., 2014). Pemberian bio-slurry dengan dosis 10.15 dan 20 ton/ha menambah kadar unsur hara yang terkandung dalam media tanam.

Dengan peningkatan pemberian dosis bio-slurry maka unsur hara terutama unsur $\mathrm{N}$, $\mathrm{P}$ dan $\mathrm{K}$ di dalam media tanam akan semakin banyak. Akan tetapi pemberian dosis bio-slurry antara 10 sampai 20 ton/ha, tidak meningkatkan pertumbuhan dan hasil tanaman wortel secara signifikan. Hal ini di duga karena kadar $\mathrm{N}$ yang terdapat pada bio-slurry yang digunakan dalam penelitian rendah $(0.12 \%)$ meskipun kadar P dan K-nya sangat tinggi, diduga aplikasi bio-slurry sampai dengan dosis 20 ton/ha belum dapat mencukupi kebutuhan tanaman wortel. $\mathrm{N}$ merupakan unsur hara esensial yang paling banyak dibutuhkan oleh tanaman dan salah satu fungsinya adalah sebagai penyusun klorofil. Bila kadar $\mathrm{N}$ dalam media tanam rendah maka jumlah $\mathrm{N}$ yang akan diperoleh tanaman juga rendah, sehingga jumlah klorofil yang terbentuk menjadi lebih sedikit dan dapat menyebabkan proses fotosintesis tidak dapat berjalan dengan baik. Doberman dan Fairhurts (2000) menyatakan bahwa pertumbuhan tanaman sangat ditentukan oleh kecukupan hara N. Unsur hara $\mathrm{N}$ memiliki fungsi menunjang pertumbuhan vegetatif tanaman sebagai komponen penyusun kolrofil sehingga dapat mendukung proses fotosintesis dengan optimal.

Hasil rata-rata panen wortel meliputi berat dan panjang umbi masih rendah. Hasil rata-rata berat umbi berkisar antara 25.76-37.41 g/umbi dan panjang umbi berkisar antara 10.82-12.41 cm/umbi masih rendah jika dibandingkan dengan hasil pada deskripsi varietas dengan hasil 120-250 g dan panjang umbi $10-20 \mathrm{~cm}$. Selain itu, hasil penelitian Arnedi (2018) yang menggunakan jenis dan berbagai dosis pupuk organik di dataran medium menghasilkan berat umbi berkisar antara 154.13-176.36 g/umbi dan panjang umbi berkisar antara $15.88-16.27 \mathrm{~cm} / \mathrm{umbi}$.

\section{Pengaruh Volume Media terhadap Pertumbuhan dan Hasil Tanaman Tanaman Wortel di Dataran Rendah}

Volume media yang berbeda $\left(2000 \mathrm{~cm}^{3}, 4000 \mathrm{~cm}^{3}, 5000 \mathrm{~cm}^{3}\right.$ dan $\left.7000 \mathrm{~cm}^{3}\right)$ berpengaruh terhadap pertumbuhan dan hasil tanaman wortel sebagaimana ditunjukkan oleh laju pertambahan panjang daun, laju pertambahan jumlah daun, berat berangkasan basah daun, berat berangkasan basah dan kering umbi dan panjang umbi (Tabel 2). Tabel 3 
menunjukan semakin besar ukuran volume media yang digunakan maka laju pertambahan panjang daun dan laju pertambahan jumlah daun cenderung semakin tinggi. Penggunaan volume media $7000 \mathrm{~cm}^{3}$ dan $5000 \mathrm{~cm}^{3}$ menghasilkan laju pertambahan panjang daun lebih tinggi (9.23 cm/2 minggu dan $8.69 \mathrm{~cm} / 2$ minggu) dari volume media $4000 \mathrm{~cm}^{3}$ dan 2000 $\mathrm{cm}^{3}$ (7.99 cm/2 minggu dan $7.51 \mathrm{~cm} / 2$ minggu) meskipun volume media $4000 \mathrm{~cm}^{3}$ tidak berbeda nyata dengan volume media $7000 \mathrm{~cm}^{3}$ dan $5000 \mathrm{~cm}^{3}$. Pada laju pertambahan jumlah daun nilai tertinggi terdapat pada volume media $5000 \mathrm{~cm}^{3}$ (2.14 helai/2 minggu) dan tidak berbeda nyata dengan volume $7000 \mathrm{~cm}^{3}$ (2.02 helai/mingggu). Hal ini menunjukan bahwa pada volume media $5000 \mathrm{~cm}^{3}$ dan $7000 \mathrm{~cm}^{3}$ mampu menunjang pertumbuhan tanaman wortel dengan baik karena pada volume media tersebut diduga mampu memberikan ruang tumbuh yang cukup untuk perkembangan akar tanaman wortel sehingga penyerapan unsur hara dapat berjalan dengan baik.

Volume media berpengaruh pada parameter berat berangkasan basah daun. berat berangkasan basah dan kering umbi dan panjang umbi. Berat berangkasan basah daun pada volume media $7000 \mathrm{~cm}^{3}(21.48 \mathrm{~g})$ dan $5000 \mathrm{~cm}^{3}(17.77 \mathrm{~g})$ didapatkan hasil yang lebih tinggi dibandingkan dengan volume media $4000 \mathrm{~cm}^{3}(11.33 \mathrm{~g})$ dan $2000 \mathrm{~cm}^{3}(8.33 \mathrm{~g})$. Pada berat berangkasan basah dan kering umbi pada volume media $7000 \mathrm{~cm}^{3}(43.20 \mathrm{~g}$ dan $6.24 \mathrm{~g})$ didapatkan hasil yang lebih tinggi dibadingkan dengan volume media lainnya meskipun tidak berbeda nyata dengan voume media $5000 \mathrm{~cm}^{3}$ (42.66 g dan $6.03 \mathrm{~g}$ ). Panjang umbi pada volume media $5000 \mathrm{~cm}^{3}(14 \mathrm{~cm})$ didapatkan hasil yang tidak berbeda jauh dengan volume media $7000 \mathrm{~cm}^{3}(13.01 \mathrm{~cm})$. Sedamgkan hasil terendah panjang umbi wortel terdapat pada volume media $2000 \mathrm{~cm}^{3}(8.88 \mathrm{~cm})$.

Uraian di atas menunjukan bahwa tanaman wortel yang ditanam pada volume media $7000 \mathrm{~cm}^{3}$ dan $5000 \mathrm{~cm}^{3}$ memiliki pertumbuhan dan hasil lebih tinggi dari tanaman pada volume media $2000 \mathrm{~cm}^{3}$ dan $4000 \mathrm{~cm}^{3}$. Hal ini diduga volume media $7000 \mathrm{~cm}^{3}$ dan 5000 $\mathrm{cm}^{3}$ yang digunakan pada penelitian ini dapat memberikan ruang tumbuh yang cukup untuk pertumbuhan tanaman wortel, selain ruang tumbuh yang cukup tanman juga memperoleh air dan unsur hara yang cukup. Selain itu, semakin besar volume media yang digunakan maka dosis bio-slurry yang diperoleh tanaman akan semakin banyak pada media tanam tersebut.

Volume media tanam menentukan luas ruang tempat tumbuh dan berkembangnya tanaman, seperti tempat tumbuhnya akar, tempat berpeganya akar dan sarana untuk menghidupi tanaman. Tanaman mendapatkan makanan yang diperlukan untuk pertumbuhan dan perkembangannya dengan menyerap unsur hara yang terkandung dalam media tanam. Volume media sangat berpengaruh terhadap pertumbuhan tanaman jika dilihat dari segi biologi. Semakin besar volume media yang digunakan maka pertumbuhan tanaman akan semakin baik karena akar dapat tumbuh dengan baik dan dapat melaksanakan fungsinya dalam menyerap unsur hara yang dibutuhkan tanaman (Muliawati, 2001).

\section{Pengaruh Interaksi Berbagai Dosis Bio-slurry dan Volume Media terhadap Pertumbuhan dan Hasil Tanaman Wortel}

Dari hasil pengamatan, pengaruh interaksi dosis bio-slurry (D) dengan volume media (V) terhadap pertumbuhan dan hasil tanaman wortel di dataran rendah tidak memberikan 
pengaruh nyata pada semua parameter yang diamati. Tidak adanya interaksi tersebut menunjukan bahwa masing-masing aras dari faktor dosis pupuk dan volume media tidak saling mendukung satu sama lain dalam mempengaruhi pertumbuhan dan hasil tanaman wortel. Menurut Sastrosupadi (2000), suatu faktor dikatakan berinteraksi dengan faktor lainnya jika pengaruh taraf faktor terebut memberikan pengaruh yang berbeda terhadap satu taraf faktor yang lain. Tidak berbeda nyatanya interaksi perlakuan dapat juga menunjukkan ada pengaruh salah satu faktor yang lebih dominan dari faktor lainnya.

\section{KESIMPULAN}

Kesimpulan pada percobaan ini adalah aplikasi pemberian dosis bio-slurry berpengaruh terhadap laju pertambahan panjang daun wortel dan tidak berpengaruh secara nyata terhadap parameter pertumbuhan lainnya dan hasil tanaman wortel di dataran rendah. Dosis 10 ton/ha dan 20 ton/ha menghasilkan pertambahan panjang daun lebih tinggi dari dosis 15 ton/ha. Volume media berpengaruh terhadap pertumbuhan (laju pertambahan panjang daun dan laju pertambahan jumlah daun, berat berangkasan basah dan berat berangkasan kering tanaman) dan hasil (berat umbi dan panjang umbi). Volume media $5000 \mathrm{~cm}^{3}$ dan $7000 \mathrm{~cm}^{3}$ menghasilkan pertumbuhan dan hasil tanaman wortel di dataran rendah lebih tinggi dari volume media $2000 \mathrm{~cm}^{3}$ dan $4000 \mathrm{~cm}^{3}$. Tidak terdapat interaksi antara dosis ampas padat biogas dan volume media dalam mempengaruhi pertumbuhan dan hasil tanaman wortel di dataran rendah.

\section{Ucapan Terimakasih}

Peneliti mengucapkan terima kasih kepada Kementrian Riset, Teknologi dan Pendidikan Tinggi serta Universitas Mataram atas dana penelitian melalui skema Student Joint Reseach Tahun 2018.

\section{DAFTAR PUSTAKA}

Adelina R., Noorhamdani dan Mustafa A. 2013. Perebusan dan Penumisan Menurunkan Kandungan Beta Karoten dalam Wortel. Gizi dan Dietetik Indonesia. 1 (3): 68 164.

Amalia, R. 2019. Pengaruh Konsentrasi dan Frekuensi Pemberian Pupuk Hayati BioEXTRIM terhadap Pertumbuhan dan Hasil Tanaman Wortel (Daucuss carota L.) dalam Pot di Dataran Rendah. Jurnal Sains Teknologi \& Lingkungan 5:112-122.

Anonim. 2015. Tentang Bio-slurry. http://www.biru.or.id/index.php//. [24 November 2018].

2018. Wortel. http://mobile.fatsecret.co.id/kalori-gizi/umum/wortel. [13 November 2018].

Arnedi, G. 2018. Respon Tanaman Wortel (Daucus carota L.) Terhadap Pemberian Berbagai Jenis dan Dosis Pupuk Organik di Dataran Medium. [Skripsi, unpublished]. Jurusan Budidaya Pertanian. Fakultas Pertanian, Universitas Mataram. Mataram. Indonesia.

Dobermenn, A. and Fairhurst T. 2000. Rice: Nutrient Disorder and Nutrient Management. International Rice Research Institude-Potash and Phospate Institude (PPI) . Canada. 
Firmansyah M. A., Liana T. dan Rahayu. 2016. Uji Adaptasi Wortel di Tanah Lempung Liat Berpasir Dataran Rendah Palangka Raya. J. Hort. 26 (2): 197-206. http://media.neliti.com. [4 Maret 2020]

Hidayat, R. 2019. Pengaruh Jarak Tanam dan Jenis Pupuk Organik pada Budidaya Tanaman Wortel (Daucus carota L.) di Dataran Rendah. [Skripsi, unpublished]. Jurusan Budidaya Pertanian. Fakultas Pertanian, Universitas Mataram. Mataram. Indonesia.

Mardin, S. dan Dewanto, E. 2013. Kajian Dosis Pupuk Organik Cair Leachate Plus dan Ketebalan Mulsa untuk Pertumbuhan dan Hasil Wortel di Dataran Rendah. Agrin 17: 130-139.

Muliawati, E. S. 2001. Kajian Tingkat Serapan Hara, Pertumbuhan dan Produksi Sambiloto (Androgaphis paniculata Ness.) pada Beberapa Komposisi Media Tanam dan Tingkat Pengairan. Prosiding Simposium Nasional II Tumbuhan Obat dan Aromatik. APINMAP. Bogor, 8-10 Agustus 2001.

Nikmatullah, A., Hadi, A.P., Suryanti, M., Tamsil, H., Hidayat, S. dan Hakim, A.R. 2018. Kajian Dampak Pemanfaatan Pekarangan Melalui KRPL di NTB 2018. Laporan Penelitian, LSPB Mataram. Mataram.

Prijatna, S. 2006. Penentuan Analisi Kimia Tanah. Fakultas Pertanian Universitas Mataram. Mataram.

Sastosupadi. 2000. Rancangan Percoban Praktis Bidang Pertanian. Kanisius. Yogyakarta.

Siahaan, B.C., Utami, S.R., dan Handyanto, E. 2014. Fitoremediasi Tanah Tercemar Merkuri Menggunakan Lindernia crustacea, Digitaria radicosa dan Cyperus rotundus serta Pengaruhnya terhadap Pertubuhan dan Produksi Tanaman Jagung. Jurnal Tanah dan Sumber Daya Lahan 1: 35-51.

Sofyan, S.E., Melya Riniarti dan Duryat. 2104. Pemanfaatan Limbah Teh, Sekam Padi, dan Arang Sekam sebagai Media Tumbuh Bibit Trembesi. Jurnal Sylva Lestari 2:6170.

Zawani, K., Nikmatullah, A., Muslim, K. dan Suryaningsih, L. 2018. Pengembangan Baby Wortel Organik di Dataran Rendah. Prosiding PKM-CRS. Hal. 1:472-477 